\title{
Determination of heavy metal content in plants rhizosphere grown under organic agriculture
}

\section{Sadržaj metala u rizosferi biljaka gajenih u organskoj proizvodnji}

\author{
Gordana Racić ${ }^{1}$, Igor Vukelić2 ${ }^{2}$ Danka Radić3 ${ }^{3}$ Mirjana Bojović4, \\ Zorana Srećkov ${ }^{5}$, Ljubinko Jovanović6 ${ }^{6}$ Dejana Panković ${ }^{7}$ \\ ${ }^{1-7}$ Educons University, Faculty of Ecological Agriculture, Vojvode Putnika 85-87, 21208 Sremska \\ Kamenica, Serbia \\ 1-7Univerzitet Edukons, Fakultet ekološke poljoprivrede, Vojvode Putnika 85-87, 21208 Sremska \\ Kamenica, Srbija
}

Rad primljen: 14.09.2020, Rad prihvaćen: 25.02.2021.

\begin{abstract}
Heavy metals in the environment when present in excess have negative effect on survival of plants causing diminished physiological and molecular activities. As they are hard to degrade, their exchangeable fraction is accumulated in plants and animals, thus entering the food chain. As one of the major concerns among consumers worldwide is food safety, organic agriculture is a promising system for its preservation.

In this work we have examined soil samples from the plant rhizosphere grown in organic production system at 5 different locations: Gložani, Svilajnac, Čenej 1, Čenej 2 and Temerin, for metal presence and chemical characteristics (soil acidity, humus content and free $\mathrm{CaCO}_{3}$ content). Determination of the total metal content ((As, $\mathrm{Cd}, \mathrm{Cr}, \mathrm{Co}, \mathrm{Cu}, \mathrm{Fe}, \mathrm{Pb}, \mathrm{Ni}, \mathrm{Zn}, \mathrm{Mn})$ ) in soil samples was performed according to EPA 6010C method using inductively coupled plasma-optima emission spectrometry (ISP-OES).

Results showed that the sampled soil is mainly of alkaline character,moderatly carbonate and rich in humus. The content of metals, at all localities, did not exceed the maximum allowed concentrations for the following metals: arsenic, cadmium, chromium, iron, manganese, nickel, lead and zinc. In the case of cobalt deviation from the MLC value was observed in four samples. However, in the case of copper only one sample exceeded MDK value. Presented results indicate that maintenance and regular soil quality control is necessary in both organic and conventional agriculture.
\end{abstract}

Keywords: ecological agriculture, ICP-OES, soil, vegetables.

Sažetak: Teški metali u životnoj sredini, kada su prisutni u većim koncentracijama, imaju negativan uticaj na biljke izazivajući smanjene fiziološke i molekularne aktivnosti. Oni se teško razgrađuju, pa se njihova lako pristupačna forma lako akumulira u biljkama i životinjama, ulazeći tako u prehrambeni lanac. Kako je jedan od glavnih problema potrošača širom sveta sigurnost hrane, organska poljoprivreda je sistem za njeno očuvanje koji se zadnjih godina promoviše.

\footnotetext{
10rcid.org/ 0000-0003-1404-4015, e-mail: gordana.racic84@gmail.com

${ }^{2}$ orcid.org/ 0000-0003-2686-0343, e-mail: igorvuk88@gmail.com

3orcid.org/0000-0002-0321-5213, e-mail: danka.radic81@gmail.com

${ }^{4}$ orcid.org/0000-0002-5767-8221, e-mail:mimatopic@gmail.com

5orcid.org/0000-0002-2278-1077, e-mail: sreckovzorana@yahoo.com

6orcid.org/0000-0002-7293-7885, e-mail: jovainko@gmail.com

7orcid.org/0000-0001-9342-1282, e-mail: dejanapankovic62@gmail.com
} 
U ovom radu rađeno je ispitivanje uzoraka zemljišta uzorkovanog iz rizosfere biljaka gajenih u organskoj proizvodnji na 5 različitih lokaliteta: Gložani, Svilajnac, Čenej 1, Čenej 2 and Temerin, Određen je pH zemljišta, sadržaj humusa i \% $\mathrm{CaCO}_{3}$. Sadržaj ukupnih metala (As, $\mathrm{Cd}, \mathrm{Cr}, \mathrm{Co}, \mathrm{Cu}, \mathrm{Fe}, \mathrm{Pb}, \mathrm{Ni}, \mathrm{Zn}, \mathrm{Mn}$ )) u uzorcima zemljišta je urađen prema metodi EPA 6010C koristeći ICP-OES spektrometriju.

Rezultati su pokazali da su ispitani uzorci bogati humusom, sa umerenim sadržajem karbonata i pretežno alkalnog karaktera. Sadržaj metala na svim lokalitetima nije prelazio maksimalno dozvoljene koncentracije za sledeće metale: arsen, kadmijum, hrom, gvožđe, mangan, nikal, olovo i cink. U slučaju kobalta odstupanje od graničnevrednosti je određeno u četiri uzorka. Međutim, u slučaju bakra samo je jedan uzorak premašio vrednost MDK. Dobijeni rezultati ukazuju da je održavanje i redovan monitoring kvaliteta zemljišta neophodan kako u organskoj tako i u konvencionalnoj poljoprivredi.

Ključne reči: ekološka poljoprivreda, ICP-OES, zemljište, povrće.

\section{INTRODUCTION}

Heavy metals are present in the environment in excess mostly due to anthropogenic factors, such as intensive industrialization, use of agrochemicals in agriculture or improper waste management. In soil they are present in different states: exchangeable, residual, organic or iron/manganase organic state (Kumar et al., 2020). Some of them (Zn, Cu, Mo, Mn, $\mathrm{Co}$, and $\mathrm{Fe}$ ) are important for plant metabolism and are defined as essential. Others, As, Pb, Cd, and $\mathrm{Hg}$, can reduce crop productivity and yield and are considered as toxic.

However, survival of plants, due to diminished physiological and molecular activities, becomes adversely affected when heavy metals are present in excess. As they are hard to degrade, their exchangeable fraction is accumulated in plants and animals (Seneviratne et al., 2017). Metals become available to the plants either from soil colloids or through influence of different abiotic factors. Some plants have developed mechanisms for metal accumulation and tolerance in roots, shoots and fruit. However, when metal concentrations overcome certain threshold values these mechanisms break down and survival of plants is at risk (Mishra et al., 2017). Bioremediation is one of ecologically friendly methods for metal removal by the use of microorganisms. The use of autochthonous microbes, i.e. the ones that are present in the plant rhizosphere, was shown to be advantageous (Danilović et al., 2012; Radić et al., 2017).

With uptake of metals by plants, they are entering the food chain. One of the major concerns among consumers worldwide is food safety, and in this context organic agriculture is a recognized system promising healthier crops and environment preservation. It is a sustainable system without the use of synthetic chemicals and therefore the soil fertility is maintained.

Successful organic production is possible through connecting crop biological properties and applied organic agro-technical measures. This means that the integrity of organic production is achieved by increasing soil fertility by appropriate crop rotation, cultivation, and the application of organic fertilizers. The system of integrated protection and biological control of diseases, pests and weeds, with specific agro-technical measures for the species, contribute to the efficient plant production and is environmentally friendly (Golijan et al., 2017).

Main aim of this work was to examine soil samples from the plant rhizosphere grown in organic production system in terms of metal presence and chemical characteristics (soil acidity, humus content and free $\mathrm{CaCO}_{3}$ content).

\section{MATERIALS AND METHODS}

\section{Soil sampling and analysis}

Soil samples were collected randomly from the plant rhizosphere grown in organic production system at 5 different locations: Gložani, Svilajnac, Čenej 1, Čenej 2 and Temerin (Table 1)

Table 1 - Locations and plant rhizosphere of samples

\begin{tabular}{|c|c|c|}
\hline $\begin{array}{c}\text { Sample } \\
\text { number }\end{array}$ & Location & Plant \\
\hline 1 & Gložani & Tomato \\
\hline 2 & Svilajnac & $\begin{array}{c}\text { Different } \\
\text { vegetables }\end{array}$ \\
\hline 3 & Čenej 1 & Carrot \\
\hline 4 & Gložani & Carrot \\
\hline 5 & Čenej 1 & Paprika \\
\hline 6 & Čenej 2 & Paprika \\
\hline 7 & Čenej 2 & Tomato \\
\hline 8 & Čenej 1 & Tomato \\
\hline 9 & Temerin & Batat \\
\hline 10 & Gložani & Paprika \\
\hline
\end{tabular}

Soil samples were placed in sterile polythylene bags and transported to laboratory. Thereafter, each soil sample was spread into a tray and divided into 
four equally sized fragments; two of which were discarded, while the remaining two were thoroughly mixed and again spread on the same tray for subsequent subsampling. For physico-chemical investigations, samples were air dried and sieved through a 0.2-mm sieve prior to analysis.

Soil acidity in 1:2.5 soil-water suspensions was determined using a Standard $\mathrm{pH}$ Meter. Humus content was determined by the permanganate method according to Iscerikov method modified by Kocman (Belić et al., 2014). The free $\mathrm{CaCO}_{3}$ content was determined by volumetric method according to Scheibler (Kacar, 2012).

\section{Metal content in soil samples}

Determination of the total metal content (As, $\mathrm{Cd}, \mathrm{Cr}, \mathrm{Co}, \mathrm{Cu}, \mathrm{Fe}, \mathrm{Pb}, \mathrm{Ni}, \mathrm{Zn}, \mathrm{Mn}$ ) in soil samples was performed according to EPA 6010C method using inductively coupled plasma-optima emission spectrometry (ISP-OES) as described previously (Stajic et al., 2016).

\section{RESULTS}

The results from the chemical analyses of the samples derived from plant rhizosphere are presented in Table 2. Examined soil types were weakly alkaline to alkaline. The lowest $\mathrm{pH}$ values were measured in sample 2 (7.30), while the highest one was determined in sample 3 (9.05). According to the humus content all samples can be classified as soils very rich in humus $(6.4 \%$ to $10.38 \%)$. The total $\mathrm{CaCO}_{3}$ content of the studied soil samples varied in the range from 0.40 to $2.09 \%$, i.e., from noncalcareous to weakly calcareous.

Table 2 - Chemical analysis of examined samples

\begin{tabular}{|c|c|c|c|}
\hline $\begin{array}{c}\text { Sample } \\
\text { number }\end{array}$ & $\mathbf{p H}\left(\mathbf{H}_{2} \mathbf{O}\right)$ & $\begin{array}{c}\text { \% humus } \\
\text { content }\end{array}$ & $\mathrm{CaCO}_{\mathbf{3}}(\%)$ \\
\hline $\mathbf{1}$ & 8,59 & 9,6 & 1,30 \\
\hline $\mathbf{2}$ & 7,30 & 8,79 & 0,23 \\
\hline $\mathbf{3}$ & 9,05 & 7,49 & 0,70 \\
\hline $\mathbf{4}$ & 8,85 & 6,77 & 0,40 \\
\hline $\mathbf{5}$ & 8,61 & 10,38 & 1,20 \\
\hline $\mathbf{6}$ & 8,057 & 9,3 & 1,799 \\
\hline $\mathbf{7}$ & 7,91 & 8,3 & 0,57 \\
\hline $\mathbf{8}$ & 7,88 & 7,6 & 2,09 \\
\hline $\mathbf{9}$ & 7,97 & 6,5 & 0,65 \\
\hline $\mathbf{1 0}$ & 8,05 & 6,4 & 1,46 \\
\hline
\end{tabular}

Total contents of metals in the examined samples are shown in Table 3. The lowest concentrations of $\mathrm{As}, \mathrm{Cr}, \mathrm{Cu}, \mathrm{Ni}, \mathrm{Pb}$ and $\mathrm{Zn}$ were found in sample number 4, from Gložani, sampled from rhizosphere of carrot. However, the lowest concentrations of Co and $\mathrm{Fe}$ were found in sample 8 form Čenej, tomato rhizosphere. The highest concentractions of $\mathrm{Cd}$, $\mathrm{Co}, \mathrm{Fe}, \mathrm{Mn}$ and $\mathrm{Pb}$ were found in sample 2 from Svilajnac, while the highest concentration of $\mathrm{Cu}$ were found in sample 1 from tomato rizosphere in Glozani, of $\mathrm{Ni}$ in sample 9 from batat rizospherer inTemerin, $\mathrm{Zn}$ in sample 10 from paprika rhizosphere in Glozani and As in sample 3 from carrot rizosphere in Čenej 1.

Table 3 - Total metal content in the examined samples with MDK (maximum allowed concentration), MLC (maximum limit concentration) and REM (remediation value)

\begin{tabular}{|c|c|c|c|c|c|c|c|c|c|c|}
\hline $\begin{array}{c}\text { Sample } \\
\text { number }\end{array}$ & $\begin{array}{c}\mathrm{As} \\
(\mathrm{mg} / \mathrm{kg})\end{array}$ & $\begin{array}{c}\mathrm{Cd} \\
(\mathrm{mg} / \mathrm{kg})\end{array}$ & $\begin{array}{c}\mathrm{Co} \\
(\mathrm{mg} / \mathrm{kg})\end{array}$ & $\begin{array}{c}\mathrm{Cr} \\
(\mathrm{mg} / \mathrm{kg})\end{array}$ & $\begin{array}{c}\mathrm{Cu} \\
(\mathrm{mg} / \mathrm{kg})\end{array}$ & $\begin{array}{c}\mathrm{Fe} \\
(\mathrm{mg} / \mathrm{kg})\end{array}$ & $\begin{array}{c}\mathrm{Mn} \\
(\mathrm{mg} / \mathrm{kg})\end{array}$ & $\begin{array}{c}\mathrm{Ni} \\
(\mathrm{mg} / \mathrm{kg})\end{array}$ & $\begin{array}{c}\mathrm{Pb} \\
(\mathrm{mg} / \mathrm{kg})\end{array}$ & $\begin{array}{c}\mathrm{Zn} \\
(\mathrm{mg} / \mathrm{kg})\end{array}$ \\
\hline 1 & 6,935 & 2,227 & 9,193 & 27,31 & 125,2 & 41,736 & 504,7 & 10,48 & 12,5 & 74,7 \\
\hline 2 & 8,881 & 2,497 & 13,17 & 47,12 & 53,36 & 45,482 & 855,4 & 15,17 & 19,53 & 79,22 \\
\hline 3 & 13,67 & 2,239 & 8,846 & 28,78 & 38,5 & 42,847 & 617,6 & 9,895 & 11,73 & 57,39 \\
\hline 4 & 4,96 & 1,799 & 8,152 & 24,26 & 26,64 & 36,957 & 497,8 & 6,938 & 7,625 & 48,15 \\
\hline 5 & 13 & 2,225 & 8,693 & 30,7 & 36,41 & 41,99 & 592 & 7,215 & 11,24 & 61,47 \\
\hline 6 & 5,166 & 1,47 & 8,22 & 43,86 & 35,9 & 22,23 & 468 & 26,65 & 9,314 & 53,19 \\
\hline 7 & 5,894 & 1,736 & 9,483 & 65,6 & 39,01 & 35,03 & 538,1 & 27,45 & 10,8 & 57,91 \\
\hline 8 & 11,21 & 1,489 & 8,135 & 35,44 & 46,39 & 22,005 & 555,9 & 30,42 & 11,37 & 68,77 \\
\hline 9 & 5,548 & 1,48 & 8,486 & 35 & 41,5 & 22,075 & 595,5 & 31,05 & 11,34 & 53,93 \\
\hline 10 & 5,536 & 1,578 & 9,33 & 33,02 & 58,18 & 23,111 & 445,1 & 28,96 & 10,96 & 79,34 \\
\hline MDK $^{*}$ & 25 & 3 & - & 100 & 100 & - & - & 50 & 100 & 300 \\
MLC $^{*}$ & 29 & 0.8 & 9 & 100 & 36 & - & - & 35 & 85 & 140 \\
REM $^{* *}$ & 55 & 12 & 240 & 380 & 190 & - & - & 210 & 530 & 720 \\
\hline
\end{tabular}

* Sl. glasnik RS, No 23/1994

** Sl. glasnik RS, No 30/2018 and 64/2019 


\section{DISCUSSION}

Soil reaction has a strong influence on the dynamics of all elements in the soil, especially microelements and heavy metals. In an acidic environment, the solubility of heavy metals increases, they and as a part of the the soil solution and they become available for plants to absorb them. In soils with an acidic reaction, calcification, i.e. raising the $\mathrm{pH}$ value above 6.5 , significantly reduces the metal solubility, and thus their toxicity to plants and organisms in the soil.

All investigated soil samples in this paper were weakly to strongly alkaline, which is in agreement with results of Vasin et al. (2013) on dominant presence of alkaline soils mainly in conventional and organic production in Serbia. Also, the same authors indicate that the humus content is higher in soils that are in organic production, which is in accordance with our data. The carbonate content of the examined samples indicated that the soils were weakly to moderately carbonate, as observed also by Vasin et al. (2013).

The presence of micro- and macro-elements in the soil is favourable in certain concentrations as they are necessary plant nutrients. However, when trace elements accumulate in larger quantities they can be harmful for all living organisms. The risk of metal negative effect strongly depends on environmental conditions. They can be present at different levels in the environment (earth, water, atmosphere). Metals can also appear as residues in food due to their presence in the environment, as a result of human activities such as agriculture, industry or contamination during food processing and storage. Humans can be exposed to these metals from the environment by ingesting contaminated food or water. Our results indicate that among examined metals concentrations of $\mathrm{Cd}, \mathrm{Co}, \mathrm{Cu}$ and $\mathrm{Ni}$ are close to maximum limit concentrations (MLC). Ninkov et al. (2012) have determined increased concentration of copper in the soil sample which was from viticultural production, and it was related to the use of Bordeaux broth which is used as a fungicide in conventional and organic viticultural production. We have also found increased concentration of copper in soil sample 1 (Gložani, tomato) indicating the use of this fungicide, which is also used in organic agriculture. It is known that long-term use of Bordeaux broth has caused an increase in the concentration of copper in the soil in many parts of the world (Lin et al., 2018). It is of high importance to examine $\mathrm{Cu}$ concentration in plant rhizosphere as high concentrations can lead to the reduction of plant biomass, inhibition of root growth, chlorosis, bronzing and necrosis which arise due to oxidative stress and creation of reactive oxygen species. Similarly, Co presence in high excess is linked to oxidative stress, photosynthesis inhibition and disruption of iron homeostasis (Lange et al., 2017). In the examined samples of plant rhizosphere higher concentration of cobalt was observed in four samples. According to MLC (Sl. glasnik RS, No 64/2019) cadmium concentration in all examined samples exceded MLC values. However, for nickel all measured concentrations were below MLC.

The concentrations of all examined metals: arsenic, cadmium, chromium, iron, manganese, nickel, lead and zinc, in soils samples were lower than maximum allowed concentrations (MDK).

\section{CONCLUSION}

Increasing people awareness on environmental protection and ecologically sustainable agriculture is a raising trend, especially in the last 50 years. Organic farming is a sustainable system where production is achieved through maintaining the quality of soil and agricultural products. In order to achieve the sustainability of organic agriculture, monitoring of soil quality for the presence of hazardous and harmful substances is needed.

In this paper, the content of 10 metals in the rhizosphere of different vegetable crops (As, Cd, Co, $\mathrm{Cr}, \mathrm{Cu}, \mathrm{Fe}, \mathrm{Mn}, \mathrm{Ni}, \mathrm{Pb}, \mathrm{Zn}$ ) was examined at five different localities. At all localities, the measured concentrations did not exceed the maximum allowed concentrations for the following metals: arsenic, cadmium, chromium, iron, manganese, nickel, lead and zinc. In the case of cobalt deviation from the MLC value was observed in four samples. However, in the case of copper only one sample exceeded MDK value. The sampled soil is mainly of alkaline character,and rich in humus.. Presented results indicate that maintenance and regular soil quality control is necessary in both organic and conventional agriculture.

\section{Acknowledgments}

This work was supported by the Ministry of Education, Science and Technological Development of the Republic of Serbia, Grant No. 172058 and 451-03-68 / 2020-14 / 200032.

\section{REFERENCES}

[1] Belić, M., Nešić, L., Ćirić, V. (2014). Praktikum iz pedologije. Univerzitet u Novom Sadu, Poljoprivredni fakultet, Novi Sad.

[2] Danilović, G., Radosavljević, S., Panković, D., Jovanović, Lj. (2012). Uloga mikroorganizama 
u bioremedijaciji zemljišta zagađenog teškim metalima. Ecologica, 19 (67), 422-425.

[3] Golijan, J., Veličković, M., Dimitrijević, B., Marković, D. (2017). Plant production by the concept of organic agriculture in the world and Serbia: History and current status. Acta Agriculturae Serbica, 22(43), 67-88.

[4] Kacar B (2012). Soil Analysis. Nobel Publications. Publication No 484, 3rd Edition, Ankara $464 \mathrm{p}$.

[5] Kumar, V., Singh, G., Chauhan, R. S., Sinam, G. (2020). Role of plant growth-promoting rhizobacteria in mitigation of heavy metals toxicity to Oryza sativa L. In: Emerging Technologies in Environmental Bioremediation (pp. 373-390). Elsevier.

[6] Lange, B., van der Ent, A., Baker, A. J. M., Echevarria, G., Mahy, G., Malaisse, F., ... Faucon, M. P. (2017). Copper and cobalt accumulation in plants: a critical assessment of the current state of knowledge. New Phytologist, 213(2), 537-551.

[7] Lin, M., Jin, M., Xu, K., He, L.,Cheng, D. (2018). Phosphate-solubilizing bacteria improve the phytoremediation efficiency of Wedelia trilobata for Cu-contaminated soil. International journal of phytoremediation, 20(8), 813-822.

[8] Mishra, J., Singh, R., Arora, N. K. (2017). Alleviation of heavy metal stress in plants and remediation of soil by rhizosphere microorganisms. Frontiers in microbiology, 8, 1706.

[9] Ninkov, J., Milić, S., Vasin, J., Kicošev, V., Sekulić, P., Zeremski, T., Maksimović, L. (2012). Heavy metals in soil and sediments of the planned ecological network of central Banat, Serbia. Ratarstvo i povrtarstvo, 49(1), 17-23.

[10] Radić, D., Jovičić-Petrović, J., Karličić, V., Racić, G., Vukelić, I., Panković, D., Raičević, V. (2018). Soil yeasts and their efficiency in stimulation of the red clover growth (Trifolium pratense L.). Ecologica, 25 (92), 899-904.

[11] Seneviratne M., Seneviratne G., Madawala H., Vithanage M. (2017). Role of Rhizospheric Microbes in Heavy Metal Uptake by Plants. In: Singh J., Seneviratne G. (eds), Agro-Environmental Sustainability. Springer, Cham. https://doi.org/10.1007/978-3-319-49727-3_8

[12] Stajic, J.M., Milenkovic, B., Pucarevic, M., Stojic, N., Vasiljevic, I., Nikezic, D. (2016). Exposure of school children to polycyclic aromatic hydrocarbons, heavy metals and radionuclides in the urban soil of Kragujevac City, central Serbia. Chemosphere, 146, 68-74.

[13] Vasin, J., Milić, S., Zeremski, T., Ninkov, J., Marinković, J., Sekulić, P. (2013). Potencijali Republike Srbije u pogledu kvaliteta zemljišta za organsku poljoprivrednu proizvodnju. Institut za ratarstvo i povrtarstvo, Novi Sad. 